\title{
ANALISIS DAYA SAING KOMODITAS IKAN LELE KABUPATEN BOGOR
}

\section{Competitiveness Analysis of Catfish Commodities of Bogor District}

\author{
Lindawati, Rikrik Rahadian dan Sonny Koeshendrajana \\ Balai Besar Penelitian Sosial Ekonomi Kelautan dan Perikanan \\ JI. KS. Tubun Petamburan VI Jakarta 10260 \\ Telp. (021) 53650162, Fax. (021)53650159 \\ Email: nda_1637@yahoo.com \\ Diterima 29 Februari 2012 - Disetujui 4 Juni 2013
}

\begin{abstract}
ABSTRAK
Nilai daya saya saing suatu produk merupakan gambaran kemampuan suatu komoditas untuk berkompetisi di pasar. Setiap komoditas yang dijual di pasar, secara natural tentunya harus berdaya saing, baik dibandingkan dengan komoditas sejenis maupun komoditas substitusinya. Ikan lele merupakan salah satu komoditas unggulan bagi program Minapolitan di Kabupaten Bogor, sehingga memiliki nilai strategis bagi pemangku kebijakan di sektor Kelautan dan Perikanan. Hingga saat ini, kajian mikro usaha budidaya ikan lele telah banyak dilakukan, namun analisis daya saing komoditas ini masih terbatas. Oleh karena itu, tulisan ini bertujuan untuk menganalisis daya saing komoditas ikan lele Kabupaten Bogor, menggunakan metode Policy Analysis Matrix (PAM). Lokasi pengumpulan data dilakukan di Kabupaten Bogor, serta Kabupaten Tulungagung - sebagai pesaing utama - untuk melihat nilai ekonomi (harga sosial) dari komoditas lele. Hasil analisis menunjukkan nilai Private Costs Ratio (PCR) sebesar 0,43, Domestic Resource Costs Ratio (DRC) sebesar 0,14, Nominal Protection Coefficient on Tradables Inputs (NPCl) sebesar 1,20 dan Nominal Protection Coefficient on Tradables Inputs (NPCl) sebesar 1,15. Keempat angka tersebut merupakan indikator dari rendahnya daya saing komoditas Lele di Kabupaten Bogor dibandingkan komoditas saingannya yang berasal dari Tulungagung. Dari hasil analisis tersebut, untuk meningkatkan daya saing komoditas ikan lele Kabupaten Bogor maka sangat diperlukan sebuah program peningkatan ketersediaan pakan yang disertai dengan program stabilisasi harga berbagai input produksi.
\end{abstract}

Kata Kunci: daya saing, ikan lele, faktor produksi domestik, input produksi

\begin{abstract}
Competitiveness value described the ability of a commodity to compete in the market. Every commodity sold in the market would naturally have to compete with its own kind or its substitutes. Catfish is a leading commodity of Minapolitan Program in Bogor District's, thus playing a major strategic role for the Ministry of Marine Affairs and Fisheries. Micro-studies on catfish farming has been extremely abundant, but competitiveness analysis for the commodity was very limited. Therefore this paper aimed at analyzing the competitiveness of Bogor District catfish product using the Policy Analysis Matrix (PAM). The primary data needed was collected in Bogor and - its main market competitor-Tulungagung District. The analysis resulted in the finding of the low competitiveness of Bogor District catfish product compared to its competitor from Tulungagung - as shown by the value of Private Costs Ratio (PCR), Domestic Resource Costs Ratio (DRC),Nominal Protection Coefficient on Tradables Inputs (NPCI) and Nominal Protection Coefficient on Output (NPCO), respectively, 0,43,; 0,14; 1,10 and 1,15. Therefore, enhancing the competitiveness of Bogor District catfish would require feed supply-increasing and input pricesstabilizing policies.
\end{abstract}

Keywords: competitiveness, catfish, domestic production factors, production inputs 


\section{PENDAHULUAN}

Ikan lele merupakan salah satu komoditas unggulan perikanan budidaya, mengingat cukup-baiknya prospek komoditas ini untuk dikembangkan. Secara faktual, akhir-akhir ini budidaya ikan lele memang relatif marak dilakukan, terutama setelah komoditas ini dijadikan salah satu komoditas unggulan dalam program minapolitan yang digulirkan oleh Kementerian Kelautan dan Perikanan (KKP). Pemilihan lele sebagai salah satu komoditas strategis tersebut, didasarkan dari cukup tingginya permintaan pasar atas komoditas ini. Ikan lele telah menjadi sumber protein yang cukup digemari oleh masyarakat luas, karena rasanya yang gurih, kandungan gizinya yang tinggi dan harganya yang terjangkau, sehingga permintaan terhadap ikan lele cenderung meningkat (Gunawan, 2010). Selain itu, para pembudidaya pun tertarik untuk berbudidaya lele disebabkan oleh beberapa faktor berikut ini: 1) budidaya lele dapat dilakukan pada lahan dengan sumber air yang terbatas; 2) padat tebar yang tinggi; 3) teknologi budidaya yang relatif sederhana; 4) relatif tahan terhadap penyakit; 5) pertumbuhannya cepat; dan $6)$ nilai ekonomis hasil yang cukup tinggi.

Menurut Direktorat Jenderal Perikanan Budidaya (2011), perkembangan produksi ikan lele secara nasional selama tahun 2005-2009 menunjukkan hasil sangat signifikan yaitu sebesar 21,82 persen per tahun dari 69.386 ton pada tahun 2005 menjadi 145.099 ton pada tahun 2009. Diperkirakan pertumbuhan produksi ikan lele secara nasional sepanjang 2010-2014 akan berkisar pada angka 450 persen atau rata-rata meningkat sebesar 35 persen per tahun yakni pada tahun 2010 sebesar 270.600 ton meningkat menjadi 900.000 ton pada tahun 2014. Hal ini menunjukkan adanya suatu target bahwa produksi ikan lele akan terus ditingkatkan untuk mengimbangi kecenderungan permintaan pasar yang terus meningkat.

Sentra pengembangan budidaya ikan lele di Jawa Barat tersebar di beberapa kabupaten, salah satunya adalah Kabupaten Bogor. Berdasarkan data statistik yang dipublikasikan oleh Dinas Kelautan dan Perikanan Jawa Barat pada tahun 2009, produksi ikan lele di Kabupaten Bogor telah mencapai 18.312,9 ton. Angka tersebut menempatkan Kabupaten Bogor sebagai penghasil ikan lele terbesar di Jawa Barat (Ditjen Perikanan Budidaya, 2011). Berdasarkan fakta tersebut, maka KKP pun menetapkan Kabupaten Bogor sebagai lokasi Minapolitan bagi komoditas lele.
Menurut Gunawan (2010), permintaan ikan lele di Jabodetabek (Jakarta, Bogor, Depok, Tangerang dan Bekasi) diperkirakan sebanyak 75 ton ikan lele konsumsi per tahunnya. Tingkat konsumsi ikan lele secara nasional pada tahun 2003 meningkat 18,3 persen, yakni dari 24.991 ton/ tahun menjadi 57.740 ton/tahun. Revitalisasi lele sampai akhir tahun 2009 menargetkan produksi sejumlah 175 ton atau meningkat rata-rata 21,64 persen per tahun. Besarnya kebutuhan dan permintaan terhadap komoditas ikan lele merupakan peluang bagi siapapun yang ingin meramaikan usaha budidaya ikan lele.

Meskipun permintaan terhadap komoditas lele ini cenderung terus meningkat, akan tetapi pemasaran komoditas lele di Kabupaten Bogor baru meliputi kawasan Jabodetabek serta Boponcur (Bogor, Puncak dan Cianjur). Bahkan pada kedua pasar tersebut, komoditas lele di Kabupaten Bogor harus pula bersaing sengit dengan produk yang sama yang dihasilkan dari lokasi lain. Adapun yang menjadi pesaing utama bagi komoditas ini adalah komoditas lele yang berasal dari Kabupaten Tulungagung.

Sayangnya, hingga saat ini, informasi mengenai besaran daya saing bagi komoditas ini masih sangat terbatas. Padahal informasi besaran daya saing lele Kabupaten Bogor akan berperan penting dalam membantu para pengambil kebijakan menentukan program apa yang harus digulirkan agar komoditas ini mampu bersaing. Oleh sebab itu, kajian ini dilakukan untuk menghasilkan informasi besaran daya saing komoditas ikan lele Kabupaten Bogor terhadap komoditas yang sama dari daerah pesaingnya yaitu KabupatenTulungagung.

\section{METODOLOGI PENELITIAN}

\section{Lokasi dan Waktu Penelitian}

Seperti telah dikemukakan pada bagian pendahuluan, maka untuk menghasilkan informasi besaran daya saing bagi komoditas Lele Kabupaten Bogor, maka pengambilan data yang diperlukan dalam kajian ini telah dilakukan di Kabupaten Bogor, Provinsi Jawa Barat, dan Kabupaten Tulungagung sepanjang Bulan Oktober 2011.

\section{Jenis dan Sumber Data}

Penelitian ini membutuhkan baik data sekunder maupun data primer. Data sekunder diperoleh dari instansi terkait seperti Dinas 
Perikanan dan Peternakan Kabupaten Bogor maupun Kabupaten Tulungagung, yang dilengkapi oleh data hasil penelusuran melalui internet. Data primer berupa struktur usaha budidaya diperoleh melalui wawancara terhadap masing-masing 30 responden pelaku budidaya Lele di kedua lokasi survei, dengan menggunakan kuesioner terstruktur. Pemilihan responden dilakukan secara sengaja (purposive sampling) dengan maksud untuk kemudahan dalam perolehan informasi.

\section{Metode Analisis Data}

Data yang telah diperoleh, selanjutnya dianalisis menggunakan metode Policy Analysis Matrix (PAM). Pada dasarnya, PAM tersusun dari empat buah kolom yang mewakili parameter penerimaan, biaya input tradable, biaya faktor domestik dan profit; serta tiga baris yang terdiri dari nilai finansial, nilai ekonomi dan divergensi dari parameter-parameter yang terdapat pada kolom, seperti yang terlihat pada Tabel 1.

Pada matriks tersebut terdapat dua jenis hasil perhitungan berupa identitas; yang pertama adalah kolom yang menunjukkan besarnya profitabilitas yang merupakan perbedaan antara penerimaan dan total biaya; dan kedua adalah baris yang mengukur dampak dari adanya divergensi (akibat dari adanya kebijakan dan kegagalan pasar) yang menunjukan perbedaan antara nilai finansial dan nilai sosial. Idealnya apabila tidak terjadi kegagalan pasar dan kebijakan yang mengakibatkan distorsi maka tidak terjadi perbedaan antara nilai finansial dan nilai sosial (divergensi) sehingga nilai-nilai parameter pada baris divergensi akan bernilai nol.

Pada dasarnya, berbagai data yang diperlukan untuk mengisi matriks tersebut berasal dari data struktur usaha budidaya. Baris nilai finansial, akan diisi dengan data rata-rata penerimaan, rata-rata biaya input, dan rata-rata biaya faktor produksi dalam satu tahun yang diperoleh dari pelaku budidaya Lele di Kabupaten Bogor. Sedangkan baris nilai sosial, sebagai pembanding, akan diisi data serupa yang diperoleh dari para pelaku budidaya Lele di Tulungagung, sebagai lokasi yang menjadi pesaing utama. Berbagai biaya yang timbul dari kegiatan usaha budidaya lele akan dikelompokkan dalam Tabel 1 menjadi biaya-biaya Tradables Inputs serta biaya Faktor Domestik, dan dimasukkan ke kolom yang bersangkutan.

Tabel 1. Formulasi Policy Analysis Matrix (PAM).

Table 1. Policy Analysis Matrix (PAM) Formulation.

\begin{tabular}{|c|c|c|c|c|}
\hline \multirow{2}{*}{$\begin{array}{l}\text { Keterangan/ } \\
\text { Description }\end{array}$} & \multirow{2}{*}{$\begin{array}{l}\text { Penerimaan/ } \\
\text { Revenue }\end{array}$} & \multicolumn{2}{|c|}{ Biaya/Costs } & \multirow{2}{*}{$\begin{array}{c}\text { Keuntungan/ } \\
\text { Profit }\end{array}$} \\
\hline & & $\begin{array}{l}\text { Input Tradable/ } \\
\text { Tradable Input }\end{array}$ & $\begin{array}{l}\text { Faktor Domestik/ } \\
\text { Domestic Factor }\end{array}$ & \\
\hline $\begin{array}{l}\text { Nilai Finansial (Harga } \\
\text { Privat) /Financia Value } \\
\text { (Private Price) }\end{array}$ & A & B & C & $\mathrm{D}$ \\
\hline $\begin{array}{l}\text { Nilai Ekonomi (Harga } \\
\text { Sosial)/Economic } \\
\text { Value (Social Price) }\end{array}$ & $E$ & $\mathrm{~F}$ & G & $\mathrm{H}$ \\
\hline Divergensi /Divergence & 1 & $\mathrm{~J}$ & $\mathrm{~K}$ & $\mathrm{~L}$ \\
\hline
\end{tabular}

Sumber: Monke \& Pearson (1989), Pearson et al. (2003) dan Khai \& Yabe (2013) /Source:Monke \& Pearson (1989, Pearson et al. (2003) and Khai \& Yabe (2013).

Keterangan/Descriptions:

$\mathrm{A}=$ Penerimaan pada harga privat/Revenue measured in private prices

$\mathrm{B}=$ Biaya input tradable pada harga privat/Tradable input costs measured in private prices

$\mathrm{C}=$ Biaya input domestik pada harga privat/Domestic input costs measured in private prices

$\mathrm{D}=$ Keuntungan pada harga privat $(\mathrm{A}-\mathrm{B}-\mathrm{C}) /$ Profit measured in private prices

$\mathrm{E}=$ Penerimaan pada harga sosial/Revenue measured in social prices

$\mathrm{F}=$ Biaya input tradable pada harga sosial/ Tradable input costs measured in social prices

$\mathrm{G}=$ Biaya input domestik pada harga sosial/ Domestic input costs measured in social prices

$\mathrm{H}=$ Keuntungan pada harga sosial (E-F-G)/ Profit measured in social prices

$\mathrm{I}$ = Penerimaan akibat dampak kebijakan dan distorsi pasar (A-E)/ Revenue due to policy and market distortion

$\mathrm{J}=$ Perbedaan biaya input tradable akibat dampak kebijakan dan distorsi pasar (B-F)/Divergence in tradable input costs due to policy and market distortion

$\mathrm{K}=$ Perbedaan biaya input domestik akibat dampak kebijakan dan distorsi pasar (C-G)/Divergence in domestic input costs due to policy and market distortion

$\mathrm{L}=$ Perbedaan pendapatan akibat dampak kebijakan dan distorsi pasar (D-H)/Divergence in revenue due to policy and market distortion 
Selanjutnya setelah tabel PAM tersebut tersusun, maka baru dapat dilakukan perhitungan beberapa indikator yang menunjukkan besaran daya saing, baik daya saing kompetitif maupun komparatif. Menurut Saptana (2010), suatu komoditas mempunyai keunggulan komparatif maupun keunggulan kompetitif maka komoditas tersebut dipandang layak untuk diproduksi. Namun, apabila suatu komoditas mempunyai keunggulan komparatif namun tidak mempunyai keunggulan kompetitif maka dipastikan adanya distorsi pasar yang merugikan produsen komoditas bersangkutan. Sedangkan Daryanto (2009) mengungkapkan bahwa lima faktor yang berpotensi sebagai penentu daya saing adalah (1) sumber daya alam dan keragaan hayati; (2) sumber daya manusia; (3) kapital atau modal; (4) teknologi dan (5) kelembagaan. Berikut ini akan dijelaskan secara singkat beberapa indikator bagi daya saing.

Indikator bagi daya saing kompetitif adalah Private Costs Ratio (PCR), yang menunjukkan berapa besar total biaya faktor produksi yang harus dialokasikan untuk menghasilkan Nilai Tambah dari kegiatan usaha sebesar Rp. 1 di lokasi penelitian. Nilai PCR di atas 1 menunjukkan tidak kompetitifnya usaha, sebaliknya nilai di bawah 1 menunjukan bahwa usaha memiliki daya saing kompetitif (Muslim dan Nurasa, 2011). Adapun cara penghitungan bagi indikator PCR ini adalah sebagai berikut:

$$
\mathrm{PCR}=\mathrm{C} /(\mathrm{A}-\mathrm{B})
$$

Indikator bagi daya saing komparatif adalah Domestic Resource Costs Ratio (DRC), yang menunjukkan berapa besartotal biaya faktor produksi yang harus dialokasikan untuk menghasilkan nilai tambah dari kegiatan usaha sebesar Rp. 1 pada harga sosial (di lokasi pembanding). Nilai DRC di atas 1 menunjukkan adanya alokasi faktor produksi yang tidak efisien dari usaha, sebaliknya nilai di bawah 1 menunjukkan bahwa usaha menggunakan faktor produksi secara efisien, sehingga memiliki daya saing komparatif. Adapun cara penghitungan bagi indikator DRC ini adalah sebagai berikut:

$$
\mathrm{DRC}=\mathrm{G} /(\mathrm{E}-\mathrm{F})
$$

Selain kedua indikator di atas, indikator lainnya yang dapat diturunkan dari PAM, yang berkaitan dengan daya saing, adalah Nominal Protection Coefficient on Tradables Inputs (NPCI) yang merupakan perbandingan antara total biaya input di lokasi penelitian dengan total biaya input pada harga sosial (di lokasi saingan), dan Nominal Protection Coefficient on Tradables Outputs (NPCO) yang merupakan perbandingan dari total pendapatan penjualan komoditas di lokasi penelitian terhadap total pendapatan penjualan komoditas pada harga sosial (di lokasi saingan). Kedua indikator ini menunjukkan ada tidaknya proteksi, pajak atau subsidi yang dikenakan terhadap harga input tradables dan harga jual dari output, sehingga terjadi distorsi dari masing-masing harga sosialnya. Nilai NPCl di atas 1 merupakan indikasi dari adanya pajak yang dikenakan terhadap input tradables, sedangkan nilai di bawah 1 merupakan indikasi dari adanya subsidi. Nilai NPCO di atas 1 menunjukan adanya proteksi terhadap output, sedangkan nilai di bawah 1 merupakan indikator dari adanya pajak yang dikenakan atas output. Adapun cara penghitungan $\mathrm{NPCl}$ dan $\mathrm{NPCO}$ adalah sebagai berikut:

$$
\begin{aligned}
& \text { NPCI }=B / F \\
& N P C O=A / E
\end{aligned}
$$

\section{HASIL DAN PEMBAHASAN}

\section{Usaha Budidaya Ikan Lele di Kabupaten Bogor dan Tulungagung}

Berdasarkan status kepemilikan usaha budidaya, pembudidaya di lokasi penelitian (Kabupaten Bogor) dibagi kedalam tiga kelompok, yaitu: (1) pemilik lahan (merupakan pembudiaya yang mengelola lahan miliknya sendiri) (2) penyewa lahan (merupakan pembudidaya yang mengelola lahan dengan membayar sewa) (3) penggarap (merupakan pembudidaya yang mengelola lahan milik orang lain tanpa menanggung modal usaha dan biaya operasional dengan sistem bagi hasil. Hasil penelitian ini menunjukkan bahwa profil status kepemilikan usaha budidaya lele di Kabupaten Bogor adalah 53 persen penyewa lahan, 40 persen adalah pemilik lahan dan 7 persen adalah penggarap.

Budidaya lele di Kabupaten Bogor dilakukan dengan teknik intensifikasi dalam rangka meningkatkan produktivitas budidaya. Masa pemeliharaan ikan lele adalah 2 (dua) bulan, dengan siklus pemeliharaan 4 (empat) kali per tahun. Ukuran ikan yang dipanen berukuran 11-12 ekor/kg dan ukuran 6-10 ekor/kg. Selain kedua ukuran tersebut, ada pula ukuran 5-7 ekor/kg yang secara khusus disalurkan untuk 
konsumen lembaga rumah makan, dan ukuran BS (ukuran 1-2 ekor/kg) untuk disalurkan ke tempat pemancingan.

Budidaya lele di Kabupaten Bogor menggunakan kolam tanah sebagai wadah budidayanya. Lahan digali dengan kedalaman kurang lebih satu meter. Pada umumnya penggalian lahan ini dilakukan selama 1-2 minggu dan tergantung pada luasan lahan yang digali. Selanjutnya lahan dikeringkan dan tanah nya dipadatkan sampai kondisi tanah padat dan kokoh. Kemudian kolam disi dengan air yang berasal dari mata air dan sungai-sungai kecil yang ada di dekat kolam. Luasan kolam yang digunakan sebagai kolam budidaya lele pada penelitian ini berkisar antara $33 \mathrm{~m}^{2}$ dan $1.800 \mathrm{~m}^{2}$ dengan luasan rata-rata $990 \mathrm{~m}^{2}$.

Usaha budidaya lele di Kabupaten Bogor menggunakan input berupa benih, pakan (pelet dan tambahan), pupuk, obat-obatan, vitamin, tenaga kerja dan lahan budidaya. Benih ikan lele yang digunakan dalam usaha pembesaran di Kabupaten Bogor sebagian besar didatangkan dari daerah Parung, Indramayu, dan Subang. Jumlah benih yang ditebar berkisar antara 4.000 ekor sampai dengan 56.000 ekor tergantung dari luas kolam budidaya. Ukuran benih yang digunakan yaitu panjang berkisar antara 5-7 cm dengan harga berkisar antara Rp.191/ekor sampai dengan Rp. 243/ekor dengan rata-rata harga benih per ekor sebesar Rp 216. Tentunya kualitas benih yang digunakan sangat berpengaruh terhadap tinggi rendahnya tingkat produksi yang dihasilkan. Dalam prakteknya, usaha budidaya ikan lele di Kabupaten Bogor dan Tulungagung terdapat beberapa perbedaan seperti yang terlihat pada Tabel 2.
Dari Tabel 2 terlihat bahwa kolam untuk usaha budidaya lele di Kabupaten Bogor terbuat dari tanah, sedangkan di Kabupaten Tulungagung menggunakan terpal. Penggunaan terpal di Tulungagung dikarenakan wilayah Tulungagung merupakan wilayah rawa yang dijadikan sebagai daerah pemukiman. Dengan kondisi tersebut, usaha budidaya harus menggunakan terpal agar air tidak cepat terserap ke dalam tanah. Jenis kolam ini mempengaruhi perlakuan penggantian air dimana penggantian air di kolam terpal tidak harus sering dilakukan sehingga pembudidaya bisa menghemat biaya listrik atau bahan bakar sebagai bahan bakar penggerak pompa air.

Selain itu, perbedaan juga terlihat dari status kepemilikan faktor produksi berupa kolam. Pembudidaya ikan lele di Kabupaten Bogor umumnya berstatus sebagai penyewa lahan, sedangkan pembudidaya ikan lele di Tulungagung mayoritas mengelola lahan milik sendiri. Perbedaan lain yang tampak adalah jumlah dan jenis penggunaan input produksi, terutama input pakan. Usaha budidaya ikan lele di Kabupaten Bogor menggunakan pakan buatan pabrik (pelet) dan juga pakan tambahan berupa carcass ayam rebus, sosis, usus ayam, dan sisa-sisa makanan. Pembudidaya juga menambah input produksi dengan pupuk urea untuk meningkatkan pertumbuhan pakan alami yang diperlukan ikan lele. Selain itu, untuk menambah daya bertahan hidup ikan, pembudidaya menggunakan obatobatan dan vitamin yang biasanya diberikan pada awal masa pemeliharaan untuk menekan tingkat kematian ikan. Perlakuan pembudidaya di Kabupaten Bogor ini tidak dilakukan oleh pembudidaya di Tulungagung yang cenderung menggunakan teknik budidaya tradisional atau semi-intensif.

Tabel 2. Perbedaan Usaha Budidaya Lele di Kabupaten Bogor danTulungagung Tahun 2011. Table 2. Head to Head, Catfish Farming Enterprises in Bogor and Tulungagung Regencies, 2011.

\begin{tabular}{|c|c|c|c|}
\hline No. & $\begin{array}{l}\text { Uraian/ } \\
\text { Descriptions }\end{array}$ & $\begin{array}{l}\text { Kabupaten Bogorl } \\
\text { Bogor Regency }\end{array}$ & $\begin{array}{l}\text { Kabupaten Tulungagung/ } \\
\text { Tulungagung Regency }\end{array}$ \\
\hline 1 & Kolam/Pond & Tanah/Land & Terpal/Tarp \\
\hline 2 & $\begin{array}{l}\text { Kepemilikan Lahan/ } \\
\text { Ownership land }\end{array}$ & Penyewa/Tenant & Milik Sendiri/Own \\
\hline 3 & $\begin{array}{l}\text { Pakan Tambahan/ } \\
\text { Additional Feed }\end{array}$ & $\begin{array}{l}\text { carcass ayam rebus, sosis, usus } \\
\text { ayam dan sisa-sisa makanan/Boiled } \\
\text { chicken carcass sausage, chicken } \\
\text { intestines and left-overs }\end{array}$ & $\begin{array}{l}\text { Tidak menggunakan pakan } \\
\text { tambahan/ } \\
\text { No additional feed }\end{array}$ \\
\hline
\end{tabular}

Sumber : (Koeshendrajana et al., 2011) dan Data Primer Diolah (2011)

Source : (Koeshendrajana et al.,2011) and Primary data processed (2011) 
Perbedaan perlakuan ini berdampak pada besarnya biaya input produksi yang harus dikeluarkan pembudidaya di Kabupaten Bogor. Jika dibandingkan dengan biaya produksi usaha budidaya lele di Tulungagung maka tampak perbedaan yang cukup signifikan bagi besarnya keuntungan yang diterima pembudidaya. Keuntungan yang diterima pembudidaya lele di Kabupaten Bogor lebih rendah sebesar 53 persen dibandingkan keuntungan pembudidaya

Tabel 3. Analisis Usaha Budidaya Ikan Lele di Kabupaten Bogor dan Kabupaten Tulungagung, Tahun 2011.

Table 3. Financial Analysis of Catfish Farming in Bogor and Tulungagung Regencies, 2011.

\begin{tabular}{|c|c|c|c|c|c|}
\hline No & Uraian/Descriptions & $\begin{array}{l}\text { Kabupaten } \\
\text { Bogor/Bogor } \\
\text { Regency (Rp) }\end{array}$ & $\%$ & $\begin{array}{l}\text { Kabupaten } \\
\text { Tulungagung/ } \\
\text { Tulungagung } \\
\text { Regency (Rp) }\end{array}$ & $\%$ \\
\hline \multirow[t]{12}{*}{1} & Investasi & & & & \\
\hline & a. Kolam/Pond & $74,350,000$ & 82.0 & $18,846,066$ & 77.6 \\
\hline & b. Rumah Jaga/Guard House & $8,528,643$ & 9.4 & $1,132,492$ & 4.7 \\
\hline & c. Pompa Air/Water Pump & $1,945,455$ & 2.1 & 629,796 & 2.6 \\
\hline & d. Gudang Pakan/Store Room & $2,400,000$ & 2.6 & 736,667 & 3.0 \\
\hline & e. Lampu Neon/Light Bulbs & 25,695 & 0.0 & 87,625 & 0.4 \\
\hline & f. Tempat Ikan/Fish Basket & 235,616 & 0.3 & - & - \\
\hline & g. Timbangan/Weight measurement & $1,075,000$ & 1.2 & 322,917 & 1.3 \\
\hline & h. Serokan/Drain & 125,972 & 0.1 & 110,166 & 0.5 \\
\hline & i. Pipa/Selang Air/Hose & 914,550 & 1.0 & $2,100,000$ & 8.7 \\
\hline & j. Jaring/Net & $1,015,714$ & 1.1 & 305,909 & 1.3 \\
\hline & Total Investasi/Total Investment & $90,616,645$ & 100.0 & $24,271,638$ & 100.0 \\
\hline \multirow[t]{5}{*}{2} & Biaya Tetap/Fixed Costs & & & & \\
\hline & a. Pajak Lahan (PBB)/Land Tax & $3,084,186$ & 32.3 & $1,899,217$ & 56.8 \\
\hline & b. Sewa Lahan/Land Rent & $6,271,421$ & 65.8 & 66,147 & 2.0 \\
\hline & c. Penyusutan aset/Depreciation & 182,016 & 1.9 & $1,378,096$ & 41.2 \\
\hline & Total Biaya Tetap / Total Fixed Cost & $9,537,623$ & 100 & $3,343,461$ & 100 \\
\hline \multirow[t]{13}{*}{3} & Biaya Operasional/Operating Costs & & & & \\
\hline & a. Pupuk Urea/Zn & 143,211 & 0.03 & - & - \\
\hline & b. Obat-obatan/Medicine & $2,836,843$ & 0.53 & $1,934,752$ & 0.44 \\
\hline & c. Vitamin/Vitamin & $8,853,946$ & 1.66 & - & - \\
\hline & d. Kapur/Calcium & 104,770 & 0.02 & - & - \\
\hline & e. Benih/Bibit/Juveniles & $20,453,514$ & 3.83 & $9,246,197$ & 2.09 \\
\hline & f. Pakan/Feed & $409,286,406$ & 76.67 & $427,233,251$ & 96.55 \\
\hline & g. Pakan Tambahan/Complementary Feed & $83,606,656$ & 15.66 & - & - \\
\hline & h. BBM/Gasoline & $1,783,879$ & 0.33 & - & - \\
\hline & i. Tenaker Panen/Harvest Labor & 654,179 & 0.12 & 560,724 & 0.13 \\
\hline & j. Biaya Perawatan/ & $1,279,833$ & 0.24 & $1,885,976$ & 0.43 \\
\hline & k. Listrik/Electricity & $4,854,056$ & 0.91 & $1,626,517$ & 0.37 \\
\hline & $\begin{array}{l}\text { Total Biaya Operasional/ } \\
\text { Total Operating Costs }\end{array}$ & $533,857,293$ & 100 & $442,487,418$ & 100 \\
\hline 4 & Total Biaya/Total Costs & $543,394,915$ & & $445,830,878$ & \\
\hline 5 & Penerimaan/Revenues & $565,257,071$ & & $492,561,555$ & \\
\hline 6 & Keuntungan/Profits & $21,862,156$ & & $46,730,677$ & \\
\hline 7 & $\mathrm{R} / \mathrm{C}$ & 1.04 & & 1.10 & \\
\hline
\end{tabular}

Sumber : (Koeshendrajana et al., 2011) dan Data primer diolah (2011)/

Source: (Koeshendrajana et al., 2011) and Primary data processed (2011)

Keterangan : Sistem bagi hasil yang digunakan antara pemilik lahan dan penggarap adalah $60 \%: 40 \%$

Description: The profit sharing agreed between landlord and tenant is $60 \%: 40 \%$ 
di Kabupaten Tulungagung dengan tingginya total biaya di Kabupaten Bogor sebesar 22\% dibandingkan Kabupaten Tulungagung. Untuk lebih jelasnya dapat dilihat pada analisis usaha budidaya lele, dengan asumsi menggunakan luasan kolam $990 \mathrm{~m}^{2}$ dan dalam waktu satu tahun (lihat Tabel 3).

Berdasarkan Tabel 3, biaya investasi yang digunakan untuk usaha budidaya ikan lele meliputi kolam/lahan, rumah jaga, pompa air, gudang pakan, lampu neon/petromak, tempat ikan, timbangan, serokan, pipa/selang air dan jaring. Persentase biaya investasi terbesar adalah untuk kolam dengan nilai 82\% untuk Kabupaten Bogor dan 77,6\% untuk Kabupaten Tulungagung. Untuk pengeluaran biaya tetap, pengeluaran untuk sewa lahan diKabupaten Bogogr lebih besar dibandingkan Tulungagung, yaitu $65,8 \%$. Hal ini dikarenakan kepemilikan lahan di Kabupaten Tulungagung merupakan milik sendiri,sedangkan di Kabupaten Bogor pembudidaya sebagai penyewa. Untuk biaya operasional pengeluaran terbesar pada faktor produksi pakan yaitu 76,67\% (Kabupaten Bogor) dan 96,55\% (Kabupaten Tulungagung). Pengeluaran faktor produksi pakan di Kabupaten Tulungagung lebih besar karena pembudidaya dalam melakukan kegiatan usahanya tidak menggunakan pakan tambahan seperti carcass ayam rebus, sosis, usus ayam.Jika dilihat dari nilai $\mathrm{R} / \mathrm{C}$ ratio, baik di Kabupaten Bogor maupun Tulungagung mempunyai nilai yang lebih besar dari satu, yang menunjukkan bahwa usaha tersebut masih layak untuk dilakukan.

\section{Analisis Daya Saing Komoditas Ikan Lele}

Dengan mempergunakan data usaha yang tertera pada Tabel 3, maka tersusunlah PAM bagi komoditas Lele seperti dapat dilihat Tabel
4. Adapun berbagai asumsi yang dipergunakan dalam penyusunan berbagai komponen pada Tabel 4 ini adalah sebagai berikut: 1) usaha budidaya dilakukan dengan luasan kolam sebesar $990 \mathrm{~m}^{2}$; 2) dengan output sebanyak $11.533 \mathrm{Kg} / \mathrm{th}$; dan 3) harga output yang diterima petani sebesar Rp. $11.224 / \mathrm{Kg}$ untuk komoditas lele dari Bogor, dan Rp. 9.780 untuk komoditas lele dari Tulungagung.

\section{Daya Saing Kompetitif dan Komparatif}

Angka PCR dan DCR - yang berkisar di bawah angka 1 (satu) - menunjukan bahwa pada dasarnya usaha budidaya lele, baik di Bogor maupun di Tulungagung memiliki daya saing baik secara kompetitif maupun komparatif, serta mampu untuk memberikan value added bagi faktor produksi yang diinvestasikan. Akan tetapi dari besaran kedua indikator tersebut $-\mathrm{PCR}=$ 0,43 ; $\mathrm{DCR}=0,14$ - dapat kita lihat bahwa usaha budidaya di Tulungagung memberikan efisiensi penggunaan faktor produksi yang lebih tinggi. Satu Rupiah value added yang dihasilkan di Bogor, akan membutuhkan investasi dalam bentuk faktor produksi sebesar Rp. 0,43; satu Rupiah value added yang di hasilkan di Tulungagung, hanya membutuhkan investasi dalam bentuk faktor produksi sebesar Rp. 0,14.

Faktor produksi yang dominan berkontribusi bagi tingginya total biaya faktor produksi komoditas lele di Kabupaten Bogor adalah kolam, sewa lahan, dan listrik. Dari ketiga faktor tersebut, kolam merupakan faktor produksi yang paling utama, terutama faktor sewa lahan karena pembudidaya lele sebagian besar berstatus usaha sebagai penyewa dan penggarap. Sementara itu, pembudidaya lele di Tulungagung umumnya berstatus usaha sebagai pemilik lahan sehingga biaya sewa tidak menjadi salah satu biaya faktor

Tabel 4. Policy Analysis Matrix (PAM) Komoditas Ikan Lele di Kabupaten Bogor Tahun 2011. Table 4. Policy Analysis Matrix (PAM) Catfish Commodities in Bogor District, 2011.

\begin{tabular}{lcccc}
\hline $\begin{array}{l}\text { Keterangan/ } \\
\text { Description }\end{array}$ & $\begin{array}{c}\text { Pendapatan/ } \\
\text { Revenue }\end{array}$ & $\begin{array}{c}\text { Input Tradables/ } \\
\text { Tradables Input }\end{array}$ & $\begin{array}{c}\text { Faktor Produksi/ } \\
\text { Factors Production }\end{array}$ & $\begin{array}{c}\text { Labal } \\
\text { Profit }\end{array}$ \\
\hline Private & $565,257,071.02$ & $527,069,224.89$ & $16,325,690.08$ & $21,862,156.05$ \\
Social & $492,561,555.33$ & $438,414,200.34$ & $7,416,677.89$ & $46,730,677.10$ \\
Divergence & $72,695,515.69$ & $88,655,024.55$ & $8,909,012.18$ & $(24,868,521.05)$ \\
& DCR & $=0.14$ & & \\
& PCR & $=0.43$ & & \\
& NPCl & $=1.20$ & & \\
& NPCO & $=1.15$ & & \\
\end{tabular}

Sumber: (Koeshendrajana et al., 2011) dan Data primer diolah (2011)/

Source: (Koeshendrajana et al., 2011) and Primary data processed (2011) 
produksi yang dominan bagi usaha budidaya lele di Tulungagung.

\section{Daya Saing Input Tradables}

Nilai $\mathrm{NPCl}$ sebesar 1,20 menunjukan bahwa terdapat inefisiensi pada penggunaan input tradables di Bogor. Inefisiensi tersebut, jika kita perhatikan struktur biaya pada tabel 3 , nampaknya disebabkan oleh adanya tambahan input pakan, obat-obatan, dan vitamin yang digunakan pada usaha budidaya lele di Bogor. Pemakaian pakan tambahan diperlukan untuk mengatasi mahalnya harga pakan buatan (pelet). Pemakaian obatobatan dan vitamin ditujukan untuk menambah daya tahan lele, agar rasio bertahan hidup (survival ratio) lele tinggi sebagai akibat dari kondisi lingkungan yang kurang baik. Selain itu, tingginya harga input benih juga menyumbang terhadap inefisiensi yang terjadi.Harga benih lele dengan ukuran 5 - 7 cm di Bogor Rp 225/ekor, sedangkan di Tulungagung hanya sebesar Rp100/ekor.

\section{Daya Saing Output}

Nilai NPCO sebesar 1,15, menunjukan bahwa terdapat indikasi adanya proteksi terhadap harga komoditas lele yang dihasilkan oleh produsen di Bogor. Proteksi yang dimaksud di sini muncul dalam bentuk diskriminisasi harga yang dilakukan oleh pelaku usaha pemasaran komoditas lele di level pengumpul,yang menguntungkan baik bagi produsen lele di Kabupaten Bogor maupun para pengumpul. Secara teoritis, para pengumpul - yang berstruktur pasar oligopsoni dan memiliki market power lebih kuat dibanding para pembudidaya yang bersaing secara sempurna - seharusnya menentukan harga beli komoditas lele Kabupaten Bogor pada tingkat yang sama dengan harga komoditas lele dari Kabupaten Tulungagung. Namun pada prakteknya, hal ini tidak terjadi, justru yang berlaku adalah para pengumpul membeli output pada harga masing-masingnya. Kondisi proteksi ini merupakan cerminan adanya vested interest di tingkat pengumpul yang sebagian besar turut juga melakukan usaha budidaya di Kabupaten Bogor. Dengan diskriminasi harga seperti ini, para produsen di Kabupaten Bogor tidak mengalami kerugian, dan para pengumpul juga memperoleh keuntungan dari penjualan komoditas lele Kabupaten Tulungagung - yang dibeli dengan harga yang lebih murah dan dijual ke para agen dan konsumen dengan harga yang sama dengan komoditas lele Kabupaten Bogor.

\section{Analisis Sensitifitas}

Dari pembahasan pada bagian terdahulu, daya saing komoditas lele Kabupaten Bogor tentunya dapat meningkat jika terjadi penurunan pada baik harga input maupun faktor produksi yang digunakan. Untuk mengetahui sejauh mana penurunan harga tersebut harus terjadi, maka dilakukan analisis sensitivitas harga-harga tersebut terhadap indikator baik PCR, DCR, NPCI maupun NPCO.

Secara parsial, komoditas lele Bogor akan memiliki daya saing input yang sebanding dengan lele Tulungagung $(\mathrm{NPCl}=1)$ jika harga pakan mengalami penurunan sebesar 22 persen, ceteris paribus. Apabila terjadi perubahan harga input secara bersama-sama, daya saing lele Bogor dapat menyamai lele Tulungagung jika harga pakan dan benih diturunkan sebesar masing-masing $21 \%$, ceteris paribus. Hal ini menunjukkan bahwa daya saing di inputtradablessedikit lebih sensitif terhadap perubahan harga input secara serentak dibandingkan secara parsial.

Pada dasarnya peningkatan daya saing di sisi faktor domestik dapat terjadi melalui penurunan harga faktor dominan berupa biaya kolam, sewa kolam, dan listrik. Dari hasil analisis sensitivitas untuk efisiensi biaya input dominan secara parsial, ternyata tidak ada satupun penurunan harga faktor secara individu yang mampu meningkatkan daya saing ikan lele di Bogor, bahkan hingga ke titik terekstrim dimana faktor produksi diberikan secara cuma-cuma. Meskipun demikian, nilai PCR dan DCR ternyata dapat sebanding jika harga kolam, sewa kolam dan listrik secara bersama-sama turun masing-masingnya sebesar 95 persen.

\section{KESIMPULAN DAN IMPLIKASI KEBIJAKAN}

\section{Kesimpulan}

Berdasarkan hasil analisis daya saing dengan menggunakan metoda PAM, diperoleh nilai PCR sebesar 0,43; DRC sebesar 0,14; NPCl sebesar 1,20 dan NPCO sebesar 1,15. Indikator PCR dan DRC tersebut menunjukan bahwa pada dasarnya komoditas lele kabupaten Bogor memiliki daya saing kompetitif, namun tidak secara komparatif. Lebih rendahnya daya saing komparatif komoditas ikan lele Kabupaten Bogor tersebut terjadi selain karena tingginya harga input tradables, juga oleh 
karena buruknya lingkungan yang menimbulkan kebutuhan atas input tambahan berupa obatobatan dan vitamin. Selain itu, dayasaing kompetitif yang dimiliki oleh komoditas lele Kabupaten Bogor, berasal dari adanya proteksi dalam bentuk diskriminasi harga yang dikenakan terhadap harga komoditas lele oleh pelaku pemasar di tingkat pengumpul.

\section{Implikasi Kebijakan}

Hasil analisis sensitifitas memberikan petunjuk bahwa untuk meningkatkan produksi serta daya saing komparatif komoditas ikan lele di Kabupaten Bogor, perlu diadakan beberapa kebijakan. Kebijakan pertama adalah penurunan dan stabilisasi harga input tradables. Kebijakan ini dapat digulirkan dalam bentuk dua buah program. Program pertama adalah peningkatan ketersediaan berbagai input produksi - terutama input produksi berupa pakan dan benih. Peningkatan ketersediaan input, selain akan mempermudah para pembudidaya untuk memperoleh akses bagi peningkatan penggunaan input produksi, juga diharapkan akan menginisiasi terjadinya peningkatan supply input di pasar, sehingga - ceteris paribus - akan mengakibatkan terjadinya penurunan harga pasar input secara otomatis, tanpa perlu adanya subsidi dari pemerintah. Program kedua adalah pembatasan jumlah pelaku usaha budidaya komoditas lele di Kabupaten Bogor. Pembatasan ini penting untuk menjaga agar tidak terjadi entry pelaku baru, yang dapat merusak stabilitas harga input tradables dari adanya peningkatan permintaan.

Kebijakan kedua adalah peningkatan produktifitas para pembudidaya lele Kabupaten Bogor. Kebijakan ini dapat dilakukan melalui program peningkatan kapasitas para pelaku usaha melalui berbagai pelatihan cara berbudidaya yang baik dan benar, serta modernisasi praktekpraktek berbudidaya. Hal ini perlu dilakukan, sebab secara faktual, hingga saat penelitian ini dilakukan, hampir seluruh pembudidaya di Kabupaten Bogor berbudidaya secara tradisional dan tidak sesuai dengan standar - sebagai contoh, penggunaan carcass sebagai pakan tambahan.

\section{DAFTAR PUSTAKA}

Daryanto, A. 2010. Minapolitan: Strategi Peningkatan Daya Saing Perikanan Berbasis Klaster. Majalah Trobos Edisi Februari 2010. Jakarta.
Ditjen Perikanan Budidaya. 2011. Bogor Sentra Budidaya Lele. http://www.perikananbudidaya.kkp.go.id/index.php?option=com_ content\&view=article\&id=80: bogor-sentra-budidaya-lele\&catid=57: berita. (Diakses tanggal 10 Februari 2012).

Gunawan, S. 2010. Kiat Sukses Budidaya Lele di Lahan Sempit. Jakarta: Agromedia Pustaka.

Kementerian Kelautan dan Perikanan. 2010. Rencana Strategis Kementerian Kelautan dan Perikanan 2010-2014. Jakarta : Kementarian Kelautan dan Perikanan.

Khai, H. V. \& M. Yabe. 2013. A Comprehensive Survey of International Soybean Research - Genetics, Physiology, Agronomy and Nitrogen Relationships: Chapter 7 - The Comparative Advantage of Soybean Production in Vietnam: A Policy Analysis Matrix Approach. INTECH.

Koeshendrajana S., Rikrik R., Cornelia M.W., Maulana F., Nensyana S., Lindawati., Estu S.L., Rani H., Budi W., Lia K.A. 2011. Laporan Teknis Riset Daya Saing Produk dan Karakteristik Pasar, Pengembangan Usaha, Investasi dan Industri Perikanan. Balai Besar Penelitan Sosial Ekonomi Kelautan dan Perikanan. Badan Penelitian dan Pengembangan Kelautan dan Perikanan. Jakarta.

Muslim, C. Dan T. Nurasa. 2011. Daya Saing Komoditas Promosi Ekspor Manggis, Sistem Pemasaran dan Kemantapannya di Dalam Negeri (Studi Kasus di Kabupaten Purwakarta, Jawa Barat). Jurnal Agro Ekonomi 29 (1): 87-111.

Monke, E.A. \& S.R. Pearson. 1989. The Policy Analysis Matrix ForAgricultural Development. Outreach Program. Standford University.

Pearson, S., C. Gotsch, \& S. Bahri. 2003. Application of the Policy Analysis Matrix in Indonesian Agriculture. Stanford University.

Saptana. 2010. Tinjauan Konseptual Mikro-Makro Daya Saing dan Strategi Pembangunan Pertanian. Forum Penelitian Agro Ekonomi 29(1): $1-18$. 